\title{
Mobile Applications in Government Services (mG-App) from User's Perspectives: A Predictive Modelling Approach
}

\author{
Authors' Details: \\ Sujeet Kumar Sharma \\ Indian Institute of Management \\ Tiruchirappalli, India \\ Email: sujeetks1@gmail.com
}

\author{
Ali Al-Badi \\ Information Systems Department \\ Sultan Qaboos University, Oman \\ Email: aalbadi@gmail.com \\ Nripendra P. Rana* \\ School of Management \\ Swansea University \\ Fabian Way, Swansea, SA1 8EN, UK \\ Email: nrananp@gmail.com \\ Laila Al-Azizi \\ Information Systems Department \\ Sultan Qaboos University, Oman \\ Email: lailaalazizi@civilpension.gov.om \\ *Corresponding author
}

\begin{abstract}
Mobile applications are becoming a preferred delivery method for the government sector and contributing to more convenient and timely services to citizens. This study examines the intention to use mobile applications for the government services (mG-App) in Oman. This study extended the Unified Theory of Acceptance and Use of Technology (UTAUT) model by including two constructs namely trust and information quality. Data were collected from 513 mobile application users across Oman. The research model was analyzed in two stages. First, structural equation modelling (SEM) was employed to determine significant determinants affecting users' acceptance of mG-App. In the second stage, a neural network model was used to validate SEM results and determine the relative importance of determinants of acceptance of $\mathrm{mG}$-App. The findings revealed that trust and performance expectancy are the strongest determinants influencing the acceptance of $\mathrm{mG}$ App. The findings of this research have provided theoretical contributions to the existing
\end{abstract}


research on mG-App and practical implications to decision-makers involved in the development and implementation of $\mathrm{mG}-\mathrm{App}$ in in Oman.

Keywords: Mobile apps, M-government, UTAUT, Trust, Information quality, Oman

\section{Introduction}

The United Nations (UN) defines electronic government (hereafter, eGov) as the use of information and communication technologies (ICTs) and its application by the government for the provision of information and public services to the citizens (UN E-Government Survey, 2014). Worldwide, governments are utilizing modernization procedures for redesigning their services to offer online public services (Veeramootoo et al. 2018). On the contrary, citizens are skeptical and cynical towards the use of mobile applications for government services (Dwivedi et al., 2017). However, mobile apps are considered one of the most significant instruments of mobile government (mGov) (Abdelghaffar \& Magdy, 2012). Mobile apps are types of software applications, which are developed to access information using mobile devices. In the present arena, mobile applications are widely used in almost all business and government domains as mobile devices are portable and facilitate access to useful services round-the-clock via Internet (Al-Masaeed \& Love, 2015). Many governments are attempting to develop mobile applications to deliver essential services to its citizens and hence there is a need to understand the effectiveness of the acceptance of such applications (Rana \& Dwivedi, 2015; Wang \& Liao, 2008). Mobile applications for government services are referred to as $\mathrm{mG}-\mathrm{App}$ throughout the paper.

The technological innovations have improved by leaps and bounds in enhancing multiple features of mobile devices in the recent past. In addition, the recent technological developments in the telecommunication sector have helped in providing services to citizens at faster rate (Biel, Grill \& Gruhn, 2010). Advanced software and hardware facilities encourage public and private institutions to offer a large number of services to mobile users (Payne, 2013). The advanced mobile devices such as smartphones/i-pads/tablets with apps provide huge opportunities to private and public institutions to minimize the digital divide between government and its residents. For example, there was a substantial increase from $50 \%$ to $58.4 \%$ was found in the use of mobile devices in African countries upon introducing mobile applications for online payments (Al-Azizi et al., 2018; Murugesan, 2013). On the basis of these statistics, it is assumed that there will be an extensive demand to create 
multiple channels for delivering government services. Mobile apps act as a form of digital assistance and are considered as one of the channels that allow individuals to interact with government services without time and location constraints.

In Oman, many government entities started to invest in and allocate a budget to initiate projects to mobilize their services through mobile applications. Mobile applications offered several online services and are considered as new channels to communicate and interact with the government stakeholders in Oman. The mobile services are ubiquitous and convenient in nature. The individuals have the facility to carry out different types of transactions such as informative or financial transactions using mobile apps. Mobile apps offer bill payments, violation payments, exchanging information between individuals and government agencies (Naqvi \& Al-Shihi, 2014). The adoption of mGov services has not yet achieved its objectives and studies have shown similar electronic government projects either have failed or faced a slow adoption process (Gao, Krogstie \& Siau, 2014). For example, $35 \%$ of eGov projects failed to implement, $50 \%$ were partially completed and only $15 \%$ were found successful in the context of developing countries (Napitupulu \& Sensuse, 2014).

Some users still prefer to pay bills and perform other financial activities through government agencies using traditional communication channels. Therefore, it is important to understand key determinants that influence their decision to accept mG-Apps. The outcomes of understanding key factors will help government in overcoming the challenges and barriers from the beginning. This study made several research contributions. First, it employed the Unified Theory of Acceptance and Use of Technology (UTAUT) to understand and predict the usage of mG-App in Oman. Secondly, it includes two additional constructs trust and information quality to better understand acceptance of mG-App. Thirdly, two staged multi-analytical models were employed: structural equation model (SEM) was employed to test the impact of determinants on the acceptance of mG-App, whereas neural network models were employed to validate SEM results and predict the importance of the key determinants of mG-App acceptance. This study has adopted multianalytical modelling as recommended by Liebana-Cabanillas et al. (2017) and Chong (2013b). Finally, the outcomes of this study will be useful to develop appropriate strategies 
to attract more users to $\mathrm{mG}-\mathrm{App}$ in the context of Oman in particular and the Arab world in general.

The remainder of this article is structured as follows: Section 2 provides the literature review followed by the proposed research model (i.e. in Section 3). The fourth section presents research methodology wherein the fifth section represents data analysis and results. Section 6 provides research implications. Finally, the conclusion, limitations and, future research directions are presented in section 7 .

\section{Literature review}

\subsection{Overview of online government services in Oman}

E-government serves as the digital collaboration within the government entities, and between the government sector, and all residents. The objective of eGov is to deliver cheap, efficient and effective service to a number of stakeholders within the government (Al-Azizi et al. 2018; Asongu \& Nwachukwu, 2016). Naqvi \& Al-Shihi (2014) reported that e-Oman was established in 2013 to administer eGov projects pertaining to infrastructure and latest technology to provide services to residents. In 2014, the UN World e-government readiness survey showed that the rank of Oman has moved from 84 to 44 since 2005 (United Nations, 2014). This rank shows that Oman government is ready for eGov implementation. However, residents of Oman still hesitate to use the latest technology. This in turn is keeping the citizens away from availing maximum benefits that the government can offer. Mobile government facilitates delivery of government services in real-time to residents using easier methods (Nixon, 2016). Furthermore, it helps in the development of new mobile services and motivate residents to interact private and public agencies around the clock (Abaza \& Saif, 2015). In Oman, there is substantially higher subscription of mobile and broadband services which can contribute to achieve strategic goals of e-Oman. Oman ranked third in 2015 among all six GCC countries for mobile subscriptions (Oman TRA, 2016). In addition, the government has taken initiative to provide free Wi-Fi at a number of locations in the capital region.

Table 1: Mobile apps in Oman

\begin{tabular}{|c|l|l|c|}
\hline $\begin{array}{c}\text { Mobile App } \\
\text { Name }\end{array}$ & \multicolumn{1}{|c|}{ Target Users } & \multicolumn{1}{|c|}{ Functions } & Type of apps \\
\hline $\begin{array}{c}\text { Ministry of } \\
\begin{array}{c}\text { Education } \\
\text { (MoE) }\end{array}\end{array}$ & $\begin{array}{l}\text { Teachers, Parents } \\
\text { (MoE, 2013) }\end{array}$ & $\begin{array}{l}\text { Enable teachers to feed the students result into the } \\
\text { application from anywhere; this app is connected to } \\
\text { Ministry portal (MOE, 2013) }\end{array}$ & Transactional App \\
\hline
\end{tabular}




\begin{tabular}{|c|c|c|c|}
\hline & & $\begin{array}{l}\text { Allow students' parents to query the results of their } \\
\text { children easily and get the ability to retrieve and } \\
\text { track their results (MOE, 2013) }\end{array}$ & \\
\hline $\begin{array}{c}\text { Public } \\
\text { Authority for } \\
\text { Consumer } \\
\text { Protection } \\
\text { (PACP) }\end{array}$ & $\begin{array}{l}\text { Serve all consumers } \\
\text { and suppliers in } \\
\text { Oman (The Public } \\
\text { Authority for } \\
\text { Consumer Protection, } \\
\text { 2000). }\end{array}$ & $\begin{array}{l}\text { - It is created to bridge the gap between the agency } \\
\text { and the consumers. } \\
\text { - Allow exchanging information on consumer's } \\
\text { goods. } \\
\text { - Enable consumer to query information such as } \\
\text { goods prices. } \\
\text { - Enable consumers to create their favorite carts to } \\
\text { compare the prices in several stores. } \\
\text { - Allow consumer to submit their complaints or } \\
\text { suggestions. } \\
\text { - Provide advices, guidance and inform about } \\
\text { authority regulations (The Public Authority for } \\
\text { Consumer Protection, 2000). }\end{array}$ & Transactional App \\
\hline $\begin{array}{l}\text { Royal Oman } \\
\text { Police (ROP) }\end{array}$ & $\begin{array}{l}\text { Serve all citizens and } \\
\text { residents } \quad \text { (Royal } \\
\text { Oman Police, 2000) }\end{array}$ & $\begin{array}{l}\text { - Traffic offense enquiry and payment. } \\
\text { - Private vehicles registration license renewal. } \\
\text { - Visa applications status inquiry. } \\
\text { - Call and locate nearby public stations listed based } \\
\text { on GPS coordination. } \\
\text { - Receive news from ROP such as accidents news, } \\
\text { announcements and crime (Al-Busaidi, 2012; } \\
\text { Royal Oman Police, 2000). }\end{array}$ & Operational App \\
\hline $\begin{array}{l}\text { Ministry of } \\
\text { Manpower } \\
(\mathrm{MoP})\end{array}$ & $\begin{array}{lr}\text { Serve all } & \text { citizens, } \\
\text { employers } & \text { and } \\
\text { residents } & \end{array}$ & $\begin{array}{l}\text { - Searching job opportunity announced by the } \\
\text { business organizations for national job seekers. } \\
\text { - Job seekers can update their information using } \\
\text { PKI authentication } \\
\text { - Employers can check the number of Omanis and } \\
\text { foreign workers in their organization. } \\
\text { - Residents can view the details of their labor cards } \\
\text { and allow them to place labor complaints (MOP, } \\
\text { 2000) }\end{array}$ & Operational App \\
\hline
\end{tabular}

The long-term plan for the Sultanate of Oman is to provide effective and interactive government services to its residents. Therefore, there is significant emphasis on the improvement in the telecommunication infrastructure in Oman. A number of mobile services have been initiated by the government agencies in the recent past. For example, Muscat Municipality was the first public agency that developed a mobile service system namely SMS-parking service system that allows drivers to pay the fees of the parking by broadcasting an SMS. This service sends an alert about the expiry time and the motorists can request an additional time and pay for it. Similarly, education sector provides services using SMS to inform the school children regarding their academic progress through a specific contact number owned by the Ministry of Education (Naqvi \& Al-Shihi, 2014). And government agencies utilized mobile services as a resource to perform their daily activities, such as sending bulk messages to their clients to inform them about new regulations. The summary of some commonly used mobile apps is presented in Table 1 . 


\subsection{Mobile government adoption}

A handful of studies (e.g. Ahmad \& Khalid, 2017; Liang et al., 2017; Liu et al., 2014; Shareef et al., 2012) have explored the mGov adoption in the last few years. For example, Shareef et al. (2012) proposed a study to address and posit the factors to understand citizen intention to adopt mGov services. Their research model for capturing users' behavior for mobile government adoption was substantially different from electronic government adoption. Liang et al. (2017) adopted a grounded theory approach to discuss the key constructs of eGov cloud adoption in China. The results of this study revealed that organizational and technological factors in addition to cloud trust were the key motivators in the acceptance of eGov cloud services. Moreover, Liu et al. (2014) conducted a research in the rural area of China to understand $\mathrm{mGov}$ adoption and found that constructs from extended technology acceptance model (TAM) along with integrity determined the acceptance of mGov. Recently, Ahmad \& Khalid (2017) conducted a research in the context of United Arab Emirates (UAE) and results revealed that trust, cost, social influence, variety of services and demographic variables in addition to TAM constructs played significant role in determining users' behavior towards mobile government services in the UAE.

\subsection{Theoretical background and hypotheses development}

UTAUT is a popular theoretical model used in the information systems research domain and emerged from eight previous theories of technology adoption (Venkatesh et al., 2003). The model aims to understand individual behavior and intention to use technology. Venkatesh et al. (2003) conducted an extensive study of eight commonly used models of technology acceptance to develop a unified model that integrate elements across all eight models to provide a comprehensive view of the behavior of users towards new technology. The idea of UTAUT model was conceived to develop a comprehensive research model on acceptance of a new technology. In addition, many studies argued that UTAUT could be considered as an effective model utilized to understand the acceptance and efficacious usage of IS in developing countries (Gupta, Dasgupta \& Gupta, 2008). Given that this model is unified in nature and the best representative of alternative models of technology 
acceptance, we have considered this as a base model for this research. There are four key constructs in UTAUT model - performance expectancy, effort expectancy, social influence and facilitating conditions. However, these constructs are not enough to represent all aspects of mobile applications in government services. The construct such as trust is essential to delivery of government IS services (Hung, Chang \& Kuo, 2013). Government agencies share useful information with private and public agencies as well as with residents to intensify the needs for trust in eGov services (such as mGov) if it has to succeed (Dwivedi et al., 2017). Although a number of studies (e.g. Alalwan et al., 2016b; Alalwan et al., 2016a; Luo et al., 2010) have explored trust and risk in the e-commerce context, only a few of them (e.g. Dwivedi et al., 2017) have tested and validated their roles in the context of mGov acceptance. However, to the best of our knowledge, no research has empirically validated the role of trust/risk toward the adoption of mobile apps for government services. Therefore, this paper has considered trust as an important external variable to analyze the understanding the relevance of trust in the mGov context. In addition, it has also been argued that the higher level of acceptance of eGov among users depends on the quality and updated information pertaining to e-services available to government websites (Chai et al., 2006). Information quality becomes even more important when it comes to receiving government services through mobile apps. Prior studies (e.g. Gilbert, Balestrini \& Littleboy, 2004; Rana et al., 2015) have stressed the importance of information quality and trust in the acceptance and success of eGov services. For example, Rana et al. (2015) found that trust and information quality (along with time, cost and financial security) were the key determinants of eGov usage. Perceived risk is not being considered in this research model as it is a surrogate variable for trust (Rana et al., 2015). Based on above discussion, we have decided to include trust and information quality as the two additional constructs in the proposed research model.

\subsubsection{Performance expectancy}

Performance expectancy is defined as the degree to which a person believes that applying the technology would help them to achieve gains in job performance (Venkatesh et al., 2003). Several studies have adopted UTAUT model and have established the fact that performance expectancy is the important predictor of behavioral intention towards 
acceptance of a new technology (Alalwan, Dwivedi \& Rana, 2017; Alalwan et al., 2015; Hanafizadeh et al., 2014; Luo et al., 2010; Venkatesh, Thong \& Xu, 2012; Venkatesh et al., 2003; Zhou, 2012). In this study, we believe that performance expectancy influences users' behavior intention towards mG-App. Residents in Oman are supposed to use mobile applications if they believe that the use of mobile applications will help them to access government services round-the-clock. In the context of Middle Eastern countries, Alalwan et al. (2017) validated the fact that performance expectancy influences the decision to adopt mobile technology. Accordingly, we propose the following hypothesis:

H1: Performance expectancy has a positive influence on behavioral intention to use mG-App.

\subsubsection{Effort expectancy}

Effort expectancy is defined as the individual's estimate of the level to which interaction with a specific system or technology required less mental and physical effort (Venkatesh et al., 2003). The UTAUT model validates that the efforts in learning a new information system influences the intention to use. The prior research (e.g. Al-Busaidi, 2012; Alalwan et al., 2015; Alalwan et al., 2017; Hanafizadeh et al., 2014; Lallmahomed et al. 2017; Venkatesh et al., 2012; Zhou, 2012) on technology adoption have also established that effort expectancy plays a significant role in the behavioral intention towards new technology. For example, Al-Busaidi (2012) highlighted the fact that there is a relationship between the complex information system and decision to use the same; the higher level of complexity associated with the information systems implies the lower acceptance by users. As per the popular acceptance model such as TAM (Davis, 1989), users are willing to accept a new technology if it is easy to use and requires no additional efforts. In case of $\mathrm{mG}-A p p$, which may require some level of knowledge and efforts, effort expectancy may influence behavioral intention towards the usage of mobile applications. Therefore, in this study we propose the following hypothesis:

H2: Effort expectancy has a positive influence on behavioral intention to use mG-App.

\subsubsection{Social influence}

Researchers (e.g. Ahmad \& Khalid, 2017; Venkatesh et al., 2012) argued that the reference groups influence the decision of users to adopt a new service when they have no or little knowledge of the service. Venkatesh et al. (2012, p.6) defined social influence as the degree 
to which consumers perceive that important others (such as family, friends, colleagues etc.) believe that they should use a particular technology. Chong (2013b) observed that social influence is the significant predictor of intention to use mobile commerce. Leong et al. (2013) also supported the aforementioned conclusion. In case of Oman, social influence is expected to influence decision of using mG-App. In this study, social influence is chosen as one of the potential predictors influencing behavioral intention on the basis of previous literature (Ahmad \& Khalid, 2017; Alalwan et al., 2015; Alalwan et al., 2017; Chong, 2013a; Lallmahomed et al. 2017; Liu et al. 2014; Martins, Oliveira \& Popovič, 2014; Venkatesh et al., 2012; Zhou, Lu \& Wang, 2010). Therefore, we propose the following hypothesis:

H3: Social influence has a positive influence on behavioral intention to use mG-App.

\subsubsection{Facilitating conditions}

Facilitating conditions are defined as the degree to which an person believes that an organizational and technical infrastructure exists to support the use of the system (Venkatesh et al., 2003). In case of mG-App, users believe that accessing multiple links, response time to upload/download files and the availability of appropriate technology are the main concerns. Lewis et al. (2013) argued that users normally need assistance to understand features when they adopt new technology. Furthermore, some other researchers (Chong, 2013a; Hew et al., 2015) also observed that users avoid using new technology when facilitating conditions are not sufficient. Chong (2013b) established that facilitating conditions influenced behavioral intention of users towards mobile commerce. On the basis of above arguments, it can be inferred that availability of good facilitating conditions would influence the decision to acceptance mG-Apps. Theoretically, facilitating conditions have been established as the key determinant of behavioral intention in a number of recently published IS studies (Alalwan et al., 2015; Alalwan et al., 2017; Ahmad \& Khalid, 2017; Chong, 2013a; Hew et al., 2015). Accordingly, we propose the following hypotheses:

H4: Facilitating conditions have a positive influence on behavioral intention to use mG-App.

\subsubsection{Trust}

Various studies on technology adoption have shown that individuals may resist or be unwilling to use the technology due to perceived trust. To explore individual attitudes toward the use of any new technology; trust as a factor may significantly influence 
residents' behavior intention to use new technology (Venkatesh et al., 2011). Williams et al. (2011) argued in their study that trust was an important determinant that influenced the adoption of information systems in many research studies. In Oman, usage of mG-App is a new phenomenon and users prefer to get involved physically for availing government services. They prefer face-to-face communication and follow up through a manual procedure to request a service or asking for information. Lack of transparency and reliability of procedures to request a service or information may cause distrust and lead to resist the usage of mobile applications. Therefore, it is important to ensure individual's convictions to perform transactions through mobile apps with confidence on these services in order to provide information (Montazemi \& Saremi, 2013). In this study, the purpose is to understand whether respondents are interested in taking risk of trusting mG-Apps. Therefore, respondents, who assume the system to be trustworthy, will have a positive influence on the behavioral intention towards mG-Apps. Therefore, we propose the following hypothesis:

H5: Trust has a positive influence on individual's behavioral intention to use mG-App.

\subsubsection{Information quality}

DeLone \& McLean (1992, 2003) defined information quality as the additional characteristics of an information system such as completeness, timeliness, accuracy and relevance. If users are receiving incomplete and irrelevant information for government services, it will have negative impact on the behavioral intention. Researchers (e.g. AlBusaidi \& Al-Shihi, 2012; Akter, D’Ambra \& Ray, 2013; Sharma et al., 2017) argued that information quality is an important determinant, which influences individual's decision to adopt a new information technology. Further, Tam \& Oliveira (2016) proved that information quality plays important role in determining the usage of mobile technology. In this study, it is proposed that information quality influences the decision to accept mG-App in Oman and hence we hypothesize the following:

H6: Information quality has a positive influence on individual's behavioral intention to use mG-App. 
Based on above discussion, Figure 1 presents the proposed research model . It is proposed that the acceptance of mobile applications for government services are driven by UTAUT constructs along with trust and information quality as two additional constructs.

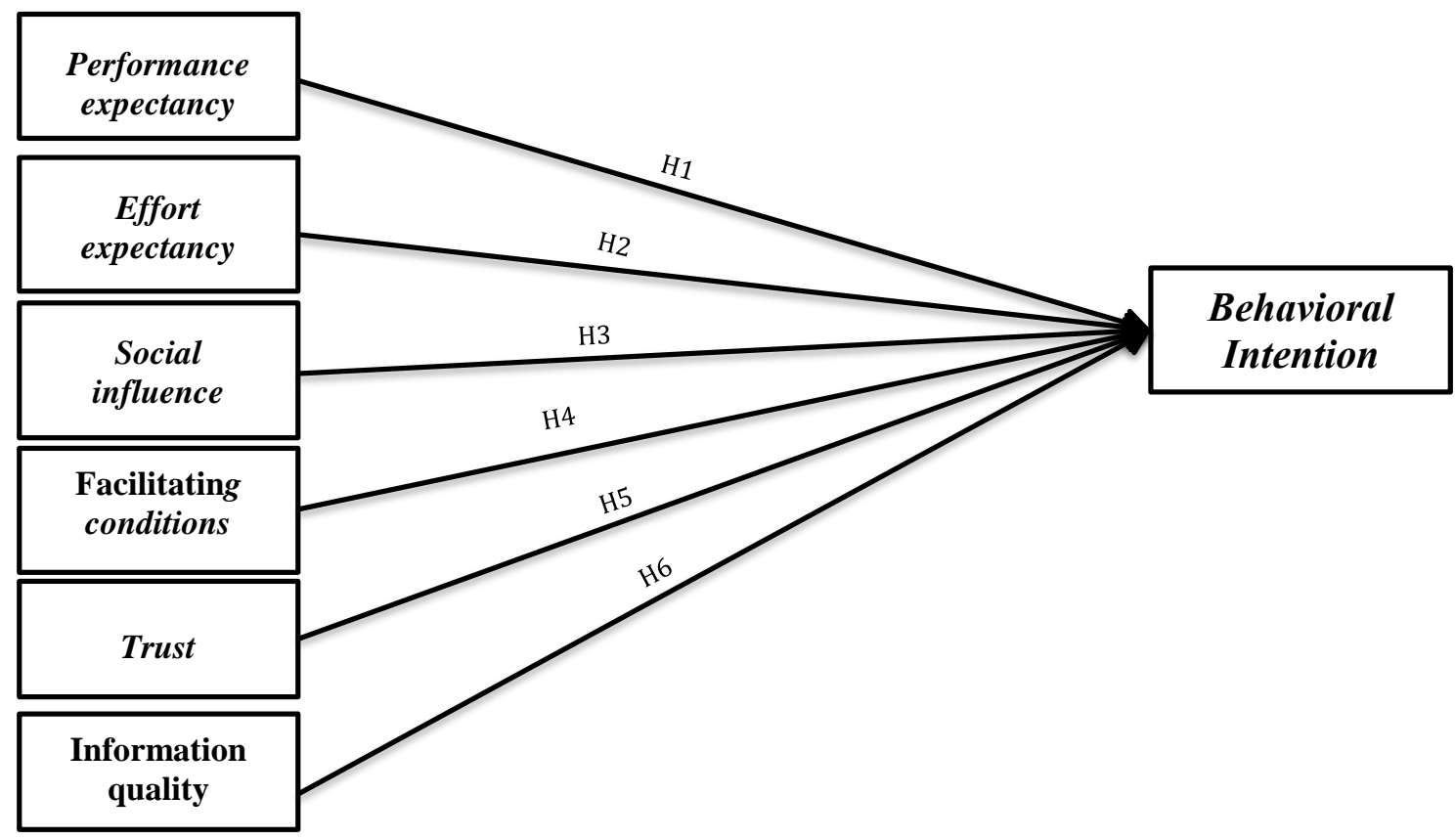

Figure 1. Proposed Research Model (Adapted from Venkatesh et al., 2003)

\section{Research methodology}

\subsection{Measurement development}

A two-step (SEM-NN) methodology (see Figure 2) was used to test the proposed research model. The questionnaire developed in this study is a tool to gather data for answering the research questions and test hypotheses. The questionnaire included summary at the beginning to explain the purpose and importance of this study. It included close-ended questions. At the beginning of each section, there is a statement that directs respondents on how to respond to the questionnaire. A pilot study was conducted to assess the reliability of the questionnaire in the month of October 2016. On the basis of the results obtained from pilot study, a survey questionnaire was modified. The questionnaire had two sections to make it easier for reading and completing. Section (A) presented demographic information in the form of multiple-choice questions such as gender, age, Internet history usage, and Internet usage per day. Section (B) included questions that represent the constructs of the proposed UTAUT based model along with two additional constructs trust and information quality. Previous studies (e.g. Rana et al., 2015, 2016, 2017; Dwivedi 
et al., 2017) have validated these instruments. Therefore, the questionnaire instruments have been adapted and wording amended as necessary without affecting the original scale in order to meet requirements of this research study. In order to encourage the respondents to express their opinions freely the items were written in simple and clear language. All statements of the UTAUT constructs along with trust and information quality determinants measured using five-point Likert-scale with possible response points including: $1=$ strongly disagree, $2=$ disagree, $3=$ neutral, $4=$ agree, $5=$ strongly agree (see appendix A for measurement items). The unbiasedness of the sample was ensured as there was no age and gender limitation enforced on the respondents. Furthermore, to address the issue of non-response bias, the comparison between respondents and non-respondents was performed using gender and age. The parametric tests results showed that there was no significant difference between respondents and non-respondents and hence non-response bias was not a serious issue in the sample.

\subsection{Data Collection}

All the respondents for this study are residents of Oman with an age 19 years or higher. Below 19 years old residents were excluded because it is assumed that there are no mobile applications that serve this age group. The sample was representative of all geographic areas of Oman as the samples were gathered from all eleven governorates i.e. Muscat, Al Dakhilia, South Al Batinah, North Al Batinah, South Al Sharqiah, North Al Sharqia, Al Buraimi, Dhofar, Musandam, Adh-Dhahirah and Al Wusta. Another reason for dividing the respondents according to their residents' governorate is the cultural and behavioral differences among those governorates, which might affect the intention to use mG-App. Therefore, the stratified sampling was used where each governorate represents a stratum and residents within each stratum are assumed to be homogenous. A sample was then drawn from each stratum. As per the National Center for Statistics and Information in Oman, the total number of residents above age of 19 years as in December 2015 was estimated to be around three million. Table 2 shows the distribution of this population according to the different governorates of Oman. 


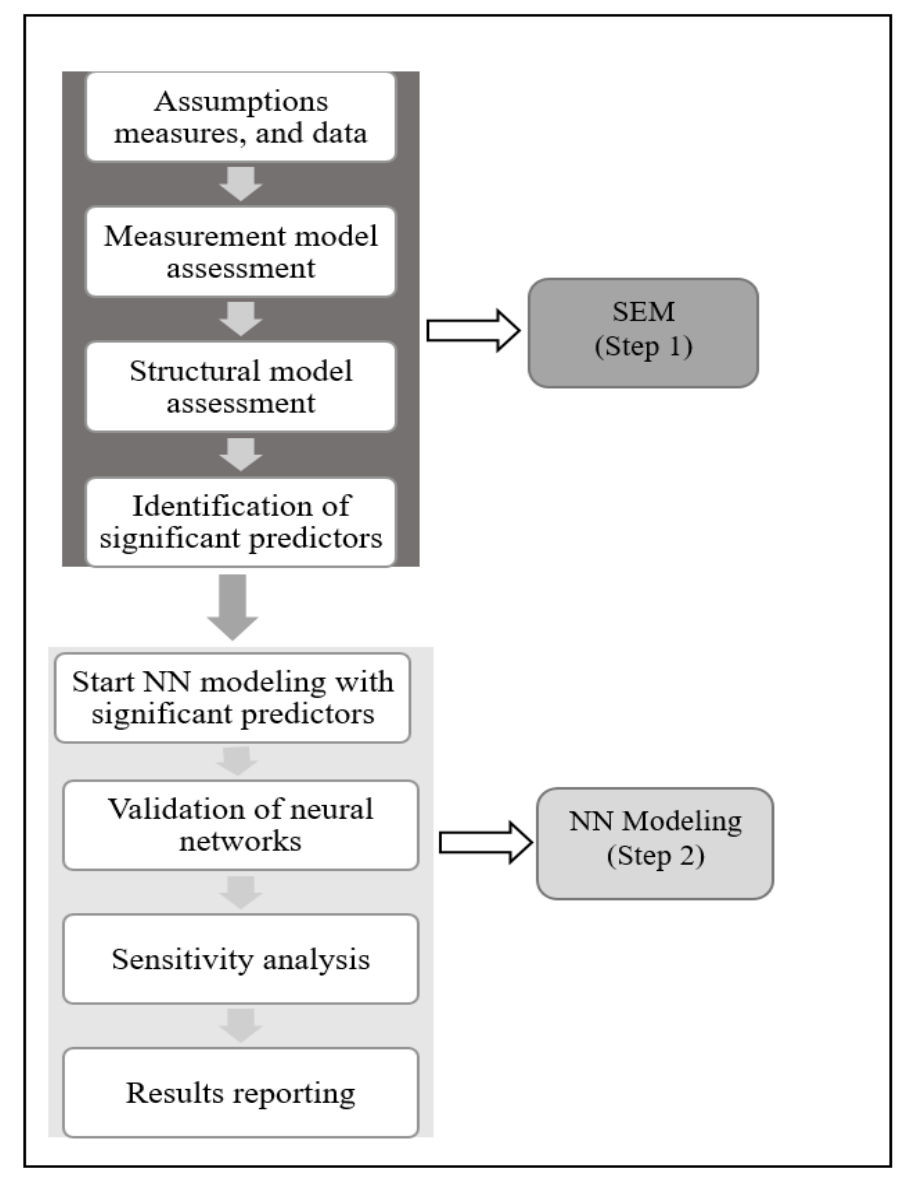

Figure 2. Two Step Methodology

After defining the stratum, the computation of sample size was calculated as follows:

$$
\text { sample size }=\frac{Z^{2} * P *(1-P)}{c^{2}}
$$

Where $\mathbf{Z}$ is the value corresponding to $95 \%$ confidence level assuming normal distribution; $\mathbf{P}$ is the percentage picking a choice; $\mathbf{c}$ is the confidence interval (Viechtbauer et al., 2015). In this research study, the values were set as follows: $Z=1.96, P=0.5, c=0.05$ and therefore the sample size was found to be 385 . However, in order to gain a high response rate, $\mathbf{4 0 0}$ individuals were chosen for this research.

Table 2: Population per governorate in December 2015

\begin{tabular}{|l|l|}
\hline Governorate & Population Size \\
\hline Muscat & $10,55,210$ \\
\hline Dhofar & $2,97,839$ \\
\hline Musandam & 29,214 \\
\hline Al Buraymi & 79,656 \\
\hline Ad-Dakhliyah & $2,73,919$ \\
\hline Al-Batinah North & $4,76,341$ \\
\hline Al-Batinah South & $2,51,690$ \\
\hline Ash-Sharqiyah South & $1,92,729$ \\
\hline
\end{tabular}




\begin{tabular}{|l|l|}
\hline Ash-Sharqiyah North & $1,77,802$ \\
\hline Adh-Dhahirah & $1,28,862$ \\
\hline Al-Wusta & 31,083 \\
\hline Total & $\mathbf{2 9 , 9 4 , 3 4 5}$ \\
\hline
\end{tabular}

The sample size was then distributed among the ten stratums proportionally according to the population size in each governorate as shown in the Table 3. Data were collected from November 2016 to February 2017.

Table 3: Sample size per governorate

\begin{tabular}{|l|c|c|c|c|}
\hline \multirow{2}{*}{ Governorate } & \multirow{2}{*}{$\begin{array}{c}\text { \% of total } \\
\text { population }\end{array}$} & \multirow{2}{*}{ Sample size } & \multicolumn{2}{|c|}{ Actual sample size } \\
\cline { 4 - 5 } & $35 \%$ & 141 & Frequencies & Percentage \\
\hline Muscat & $10 \%$ & 40 & 209 & 40.7 \\
\hline Dhofar & $1 \%$ & 4 & 33 & 6.4 \\
\hline Musandam & $3 \%$ & 10 & 10 & 1.9 \\
\hline Al Buraymi & $9 \%$ & 36 & 98 & 2.3 \\
\hline Ad-Dakhliyah & $16 \%$ & 64 & 42 & 19.1 \\
\hline Al-Batinah North & $8 \%$ & 34 & 39 & 8.2 \\
\hline Al-Batinah South & $6 \%$ & 26 & 10 & 7.6 \\
\hline Ash-Sharqiyah South & $6 \%$ & 24 & 23 & 4.9 \\
\hline Ash-Sharqiyah North & $4 \%$ & 17 & 35 & 6.5 \\
\hline Adh-Dhahirah & $1 \%$ & 4 & 2 & 0.4 \\
\hline Al-Wusta & $100 \%$ & 400 & 513 & 100.0 \\
\hline Total & & & & \\
\hline
\end{tabular}

Two reminders were sent to those respondents during aforementioned period who did not complete the survey.

\section{Data analysis and results}

\subsection{Descriptive statistics of the sample}

The sample in this study contains a total of 513 respondents out of which $48 \%$ (i.e. 247 respondents) are female and 52\% (i.e. 266 respondents) are male. This sample is also of relatively young age as $44 \%$ (i.e. 224 respondents) are in the age range of 20-29 years, 37\% (i.e. 191 respondents) are in the age range of 30-39 years whereas only $19.1 \%$ of the respondents were found in the age group of 40 years and above. The study sample also comprises of relatively well-educated individuals as $69 \%$ (i.e. 352 respondents) have university degree, $15 \%$ (i.e. 78 respondents) are postgraduate degree holders, $12 \%$ (i.e. 63 respondents) have secondary school whereas only $3 \%$ (i.e. 17 respondents) have $\mathrm{PhD}$ and the remaining small percentage of about $0.6 \%$ ( 3 respondents) were illiterate. The study sample also represents Internet experience in terms of frequency of Internet usage in last 7 days. It indicates the time-length the respondents spent in using the Internet. The $38 \%$ (i.e. 194 respondents) of respondents browsed the Internet for 1-to-5 hours, while around 24\% 
(i.e. 122 respondents) used the Internet between 6-to-10 hours and about 37\% (i.e. 189 respondents) spent more than 11 hours browsing the Internet.

Table 4: Demographic information of the sample

\begin{tabular}{|c|c|c|c|}
\hline \multicolumn{2}{|l|}{ Demographic Trait } & \multirow{2}{*}{$\frac{\text { Frequency }}{247}$} & \multirow{2}{*}{$\frac{\text { Percentage }}{48.0}$} \\
\hline Gender & Female & & \\
\hline & Male & 266 & 52.0 \\
\hline \multirow[t]{5}{*}{ Education level } & Secondary school & 63 & 12.3 \\
\hline & University degree & 352 & 69.0 \\
\hline & Master & 78 & 15.2 \\
\hline & Ph.D. & 17 & 3.3 \\
\hline & Illiterate & 3 & 0.6 \\
\hline \multirow[t]{3}{*}{ Age } & $20-29$ years & 224 & 44.0 \\
\hline & $30-39$ years & 191 & 37.2 \\
\hline & $40+$ years & 98 & 19.2 \\
\hline \multirow[t]{5}{*}{ Frequency Internet usage per day } & 1 to 5 hours & 194 & 38.0 \\
\hline & 6 to 10 hours & 122 & 24.0 \\
\hline & 11 to 15 hours & 74 & 14.4 \\
\hline & 16 hours or more & 115 & 22.4 \\
\hline & None & 8 & 1.6 \\
\hline \multirow{5}{*}{ Internet history usage } & $1-4$ years & 50 & 10.0 \\
\hline & $5-7$ years & 93 & 18.1 \\
\hline & 8 years and above & 362 & 70.6 \\
\hline & Don't use & 5 & 1.0 \\
\hline & Less than one year & 3 & 0.6 \\
\hline
\end{tabular}

In addition, the sample also indicates the Internet use history. It shows that the majority of respondents $71 \%$ (i.e. 362 respondents) had more than 8 years using the Internet. Also, the sample shows around 18\% (i.e. 93 respondents) are using the Internet for around 5-7 years whilst approximately $10 \%$ (i.e. 50 respondents) had been using the Internet for 1-4 years. As shown in Table 4, only 6\% (i.e. 3 respondents) had used the Internet less than a year and those not using the Internet were $1 \%$ only. The findings indicate that there is a high usage of Internet among the sample. Table 4 shows summary of the demographic variables of the sample.

\subsection{Testing constructs normality}

Normal distribution test is important to assess the normality assumption, which should be taken into considerations for employing parametric statistical tests (Bennet, Sankaranarayanan \& Babu, 2015). In this study normality is tested using statistical technique such as Pearson's Skewness and Kurtosis parameters. The acceptable range of 
these parameters is between -2.58 to +2.58 (Azzalini et al., 2014). The results indicate that all values of the variables were within acceptable range and therefore it can be concluded that data is normally distributed.

Table 5. Skewness and kurtosis for the research constructs

\begin{tabular}{lccccccc}
\hline & \multicolumn{1}{c}{ Statistics } \\
& $\begin{array}{c}\text { Performance } \\
\text { Expectancy }\end{array}$ & $\begin{array}{c}\text { Effort } \\
\text { Expectancy }\end{array}$ & $\begin{array}{c}\text { Social } \\
\text { Influence }\end{array}$ & $\begin{array}{c}\text { Facilitating } \\
\text { Conditions }\end{array}$ & $\begin{array}{c}\text { Behavioral } \\
\text { Intention }\end{array}$ & $\begin{array}{c}\text { Trust } \\
\text { Information } \\
\text { Quality }\end{array}$ \\
\hline Skewness & -1.40 & -0.80 & -0.21 & -0.60 & -0.95 & -0.27 & -0.23 \\
\hline Kurtosis & 2.672 & 1.828 & 0.631 & 1.134 & 1.332 & -0.197 & 0.691 \\
\hline
\end{tabular}

\subsection{Reliability}

Reliability of the constructs is used to measure the consistency across items of each measurement scale. Cronbach's alpha is used to compute the average of inter-item correlations and measurement of internal consistency. The acceptable reliability scale should be 0.70 and above to indicate internal consistency (Bonett \& Wright, 2015). SPSS package was used to compute the reliability coefficient for each construct. The Cronbach's alpha $(a)$ values are summarized in appendix A.

\subsection{Confirmatory Factor Analysis (CFA)}

Two-step analysis was applied with the aim to first examine the measurement model and then assess the hypotheses by examining the fitting of structural model. Confirmatory Factor Analysis (CFA) was performed to define the goodness-of-fit between the model's constructs and the collected data. The goodness-of-fit was achieved by the assessment of convergent validity, discriminate validity and construct reliability. CFA was performed using AMOS 24 to compute the required results (Byrne, 2016).

\subsubsection{Convergent Validity and Discriminant Validity}

Convergent validity aims to test the association between several measurement scales. It is considered as one type of construct validity, which acts as an instrument associated highly with other scales and constructs that are hypothetically related. Convergent validity primarily depends on average variance extracted (AVE). The AVE is used to compute the explanatory power of the variables of the measurement to the average variations (Alarcón \& Sánchez, 2015). In this study, AVE and composite reliability (CR) were used to examine the convergent validity of the constructs. As a rule of thumb, AVE should be above 0.50 in order to be considered as high convergent validity and high reliability. Discriminate 
validity is used to check whether respondents' answers to the survey items are either lightly correlated or not correlated at all with other latent variables (Alarcón \& Sánchez, 2015). The values of MSV to be less than the values of AVE for each construct confirms the discriminant validity. Table 6 shows that all composite reliabilities (CR) are above the criterion of 0.70 , which is a signal that there is no overlap between the constructs. Furthermore, Table 6 represents that AVE for each construct is above the criterion of 0.50 . Convergent validity was validated as CR values are greater than AVE. AVE indicates values greater than the recommended rule of thumbs of 0.50 . Hence, the reliability of all constructs is at acceptable level. In addition, factor loading (see appendix A) of the all constructs are also at acceptable level.

Table 6. Convergent validity and Discriminant Validity Results

\begin{tabular}{|l|l|l|l|l|c|c|c|c|c|c|c|}
\hline VR & CR & AVE & MSV & MaxR(H) & EE & PE & SI & FC & BI & TR & QU \\
\cline { 2 - 13 } & 0.835 & 0.559 & 0.529 & 0.841 & $\mathbf{0 . 7 4 8}$ & & & & & & \\
\hline PE & 0.868 & 0.623 & 0.529 & 0.925 & 0.727 & $\mathbf{0 . 7 8 9}$ & & & & & \\
\hline SI & 0.820 & 0.695 & 0.239 & 0.944 & 0.264 & 0.243 & $\mathbf{0 . 8 3 4}$ & & & & \\
\hline FC & 0.738 & 0.587 & 0.523 & 0.952 & 0.723 & 0.566 & 0.157 & $\mathbf{0 . 7 6 6}$ & & & \\
\hline BI & 0.893 & 0.736 & 0.417 & 0.968 & 0.646 & 0.600 & 0.226 & 0.595 & $\mathbf{0 . 8 5 8}$ & & \\
\hline TR & 0.925 & 0.755 & 0.487 & 0.977 & 0.563 & 0.467 & 0.362 & 0.454 & 0.475 & $\mathbf{0 . 8 6 9}$ & \\
\hline IQ & 0.783 & 0.547 & 0.487 & 0.979 & 0.675 & 0.533 & 0.489 & 0.522 & 0.549 & 0.698 & $\mathbf{0 . 7 4 0}$ \\
\hline
\end{tabular}

Note: AVE: Average Variance Extracted, CR: Composite Reliability; MSV: Maximum Shared squared Variance; $\operatorname{MaxR}(\mathrm{H})$, Maximum Reliability, VR: Variable

Table 6 also indicates that all values of the square root of the AVE across the diagonal cells are greater than the inter-correlations between constructs, which tested the discriminant validity of the scales and supported it.

\subsubsection{Measurement Model Assessment}

The measurement model was analysed using AMOS 24.0 and helps to evaluate the indicators, which used to validate the latent variables. The fit measures were computed to test the model fit with the collected data. The most popular fit measures that are included to evaluate the model fit indices are: Goodness of Fit Index (GFI)=0.93; Adjusted Goodness of Fit Index $(\mathrm{AGFI})=0.91$, which adjust the value to the degrees of freedom in the model. The Normed Fit Index $(\mathrm{NFI})=0.94$, which assesses the incremental fit of the model and the Root Mean Residual $(\mathrm{RMR})=0.06$, which assesses the residual variance of the observed variables indicate how the variance of the variables correlate with the residual variances for the other items whereas Root Mean Square Error of Approximation $($ RMSEA $)=0.048$ estimates the lack of fit in the model compared to a perfect model (Byrne, 
2016; Raitoharju, 2014). The aforementioned fit indices result show that most of the fit indices lead to good model fit. Hence, measurement model is a good fit to the data.

\subsection{Hypotheses Testing: Results of Structural Model}

The structural model assessment follows different procedures, which include assessing the squared multiple correlations, an inspection of the model fit indices and the standardized path coefficients. The SEM provides indications on the strength, significance or insignificance of each path. The rule of thumb used in this structural assessment is the same to the rules used in measurement test. The results show that the overall model indicates a good-fit with Chi-square $\left(\chi^{2}\right)=593.39$, degree of freedom $(d f=213), \chi^{2} / d f=2.78$, pvalue $<0.001$. The normed Chi-square value of 2.78 indicates very good because it is lower than 3.0, the CFI, NFI, TLI and AGFI are above 0.90 and RMSEA=0.056 is less than the cut-off point of 0.06 (Byrne, 2016). In this study six hypotheses were tested. The beta values indicate the weight of each path and examine its strength (Al-Busaidi, 2012). The results revealed that the proposed research model explained an overall variance of $64 \%$ in behavioral intention. This demonstrates the significant impact of factors such as performance expectancy, effort expectancy, facilitating conditions, trust, and information quality in predicting individual's intention toward mG-App acceptance.

Table 7. Hypotheses results

\begin{tabular}{cccccc}
\hline Hypothesis & Path & Estimate & S.E. & p-value & Supported \\
\hline $\mathrm{H} 1$ & $\mathrm{PE} \rightarrow \mathrm{BI}$ & 0.332 & 0.075 & 0.000 & YES \\
\hline $\mathrm{H} 2$ & $\mathrm{EE} \rightarrow \mathrm{BI}$ & 0.236 & 0.049 & 0.000 & YES \\
\hline $\mathrm{H} 3$ & $\mathrm{SI} \rightarrow \mathrm{BI}$ & 0.043 & 0.040 & 0.282 & NO \\
\hline $\mathrm{H} 4$ & $\mathrm{FC} \rightarrow \mathrm{BI}$ & 0.117 & 0.054 & 0.031 & YES \\
\hline $\mathrm{H} 5$ & $\mathrm{TR} \rightarrow \mathrm{BI}$ & 0.371 & 0.066 & 0.000 & YES \\
\hline $\mathrm{H} 6$ & $\mathrm{IQ} \rightarrow \mathrm{BI}$ & 0.163 & 0.066 & 0.014 & YES \\
\hline
\end{tabular}

In order to confirm the support of hypothesized relationships it is recommended that standardized path coefficients to be significant at $\mathrm{p}<0.05$ to its minimum (Byrne, 2016). The findings show that five out of six hypotheses are supported (see Table 7).

\subsection{Artificial Neural Network (ANN) approach}

This study employed an innovative and hybrid SEM and neural network - a popular machine learning tool. The traditional statistical models such as multiple linear regression, and structural equation model are often not enough to develop efficient model to 
understand complexity of business decision making (Liébana-Cabanillas et al., 2017; Sim et al., 2014). ANN is an enormously parallel distributed processor made up of simple processing units, which have a neural inclination for storing experimental knowledge and making it available for use (Haykin, 2001). The advantage of employing neural network in complex business decision making problems is to detect linear as well as nonlinear relationships among decision variables. A number of different types of neural network models are available in the literature. We have employed the commonly used neural network model namely feedforward back-propagation multilayer perceptron (Chong, 2013b; Chiang et al., 2006; Leong et al., 2013; Liébana-Cabanillas et al., 2017). There are generally three layers in artificial neural network model namely input layer, hidden layer and output layer. In an artificial neural network, there is a possibility to develop a large number of hidden layers. In fact, we need higher number of hidden layers to solve problems with complexity of the higher order. Any continuous function can be handled with one hidden layer. The number of input layers is equal to the number of independent variables and output variable is equal to one i.e. one dependent variable. The activation function used in an artificial neural network model to capture relationship among decision variables is sigmoid function, i.e. a hyperbolic tangent. The purpose of using a hyperbolic tangent function is its capability to squeeze data together at low and high ends of the original dataset (Chiang, Zhang \& Zhou, 2006). Artificial neural network model is capable to identify nonlinear relation in addition to linear relation between independent and dependent variables. Furthermore, an artificial neural network model does not need to test requirements of any data distribution such as linearity, normality and independence (Chong, 2013b; Chiang et al., 2006; Liébana-Cabanillas et al., 2017). There are number of successful applications of artificial neural network models in solving complex business problems such as mobile credit card acceptance (Leong et al., 2013), mobile commerce (Chong, 2013b), mobile learning (Tan et al., 2014), RFID acceptance in healthcare (Chong et al., 2015), Facebook acceptance in academics (Sharma, Joshi \& Sharma, 2016), mobile commerce acceptance (Liébana-Cabanillas et al., 2017), e-learning management systems (Sharma et al., 2017) and in many other information system domains.

\subsubsection{Validations of neural networks}


In this research study, an artificial neural network model was analysed using a popular statistical software package SPSS 23.0. The back propagation multilayer perceptron neural network model was used to describe the neural networks and the variables that the user can control during training of a neural network (Poulton, 2001). To avoid overfitting of the model, a ten-fold cross validation approach was employed. Cross validation splits data set into $\mathrm{N}$ equal size groups. In this study, we have divided data into 10 equal groups. Furthermore, cross validation helps in testing the out sample error of the model. Researchers (Sexton, Johnson \& Hignite, 2002; Chong, 2013b; Liébana-Cabanillas et al., 2017) argued that there is no procedure available to compute exact number of nodes in a neural network model. Hence, ten nodes were employed in the neural network model. The predictive accuracy of the NN model was evaluated using Root Mean Square of Error (RMSE) as recommended by a number of scholars (Chiang et al., 2006; Chong, 2013b; Chong et al., 2015; Liébana-Cabanillas et al., 2017; Sharma et al., 2016; Sharma et al., 2017; Tan et al., 2014). A ten-fold cross validation approach was adopted with $80 \%$ datasets for training neural network model and $20 \%$ for testing purposes.

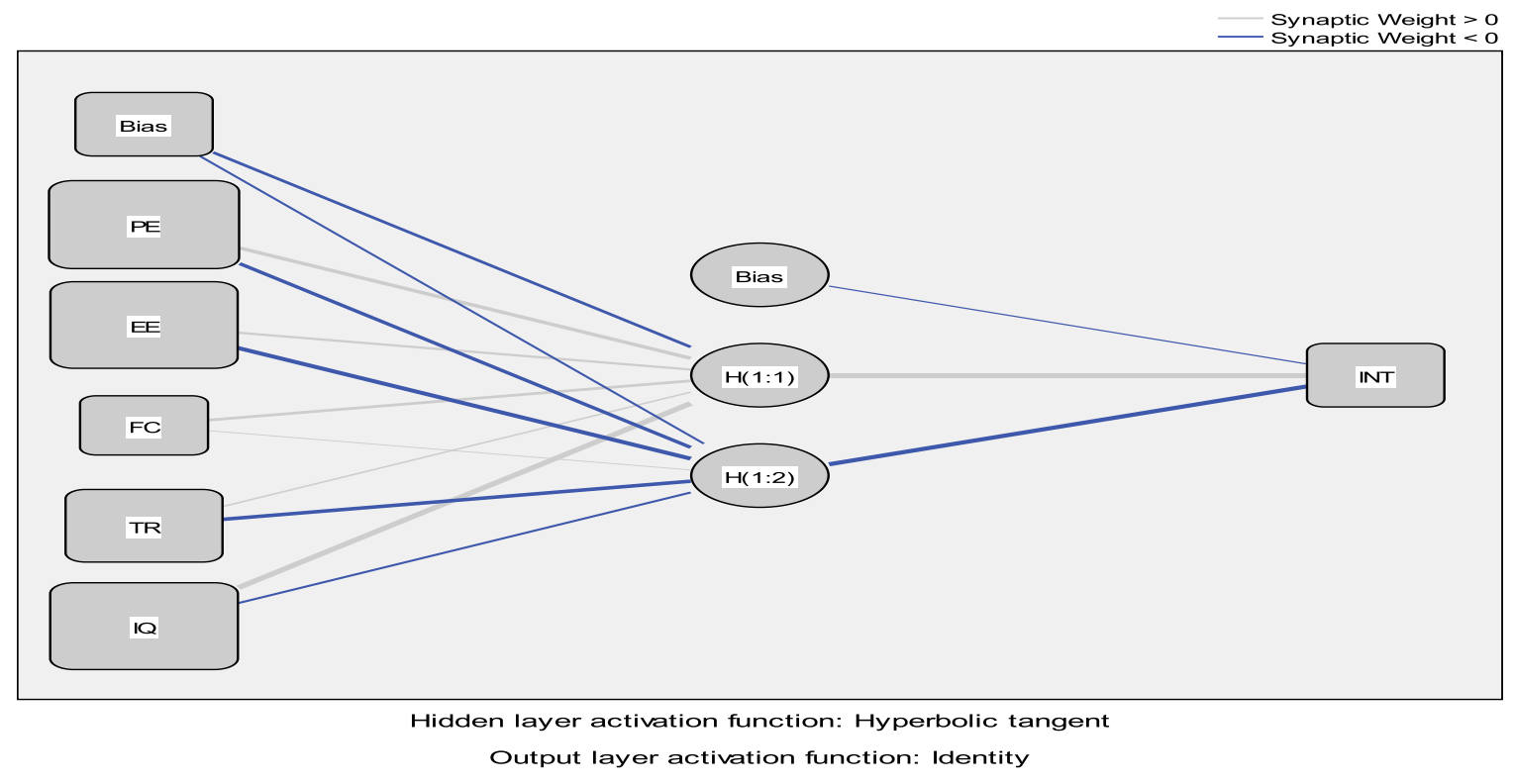

Figure 3. Neural network model

The key constructs namely performance expectancy, social influence, facilitating conditions, trust and information quality were used as input layer and mobile applications acceptance for government services was used as output layer (see Figure 3). In the neural 
network developed for this study, one hidden layer was employed, as it is enough to represent a continuous function. The RMSE values for training and testing models are summarized in Table 8. On the basis of relatively small RMSE values (i.e. average RMSE for training model as 0.098 and average RMSE for testing model as 0.108), we can conclude that the results obtained from the neural network model were quite accurate as suggested by prior research (Chong, 2013b; Chong et al., 2015; Liébana-Cabanillas et al., 2017; Sharma et al., 2016; Sharma et al., 2017; Tan et al., 2014).

Table 8. Neural Network Validations

\begin{tabular}{|c|c|c|}
\hline Network & Testing & Training \\
\hline ANN1 & 0.122 & 0.114 \\
\hline ANN2 & 0.116 & 0.109 \\
\hline ANN3 & 0.108 & 0.102 \\
\hline ANN4 & 0.109 & 0.098 \\
\hline ANN5 & 0.092 & 0.079 \\
\hline ANN6 & 0.087 & 0.081 \\
\hline ANN7 & 0.117 & 0.112 \\
\hline ANN8 & 0.105 & 0.093 \\
\hline ANN9 & 0.119 & 0.103 \\
\hline ANN10 & 0.101 & 0.092 \\
\hline Average & 0.108 & 0.098 \\
\hline
\end{tabular}

\subsubsection{Sensitivity Analysis}

The importance of independent variables influencing the decision to accept mG-App is a measure of variation in the prediction of different values of independent variables (Chong, 2013b; Liébana-Cabanillas et al., 2017). The normalized importance is calculated by dividing importance of each independent variable to the maximum importance value (see Table 9).

Table 9. Independent Variable Importance

\begin{tabular}{ccc}
\hline Constructs & Importance & Normalized Importance (\%) \\
\hline PE & 0.275 & 100.0 \\
TR & 0.267 & 97.1 \\
EE & 0.220 & 80.0 \\
IQ & 0.150 & 54.6 \\
FC & 0.088 & 32.0 \\
\hline
\end{tabular}

Based on the results obtained from neural network analysis, it is observed that the performance expectancy is the most important predictor of the mG-App followed by trust, effort expectancy, information quality and facilitation conditions.

It is interesting to note that performance expectancy is the most influential factor in determining intention to use mobile applications. However, trust was found as the most 
influential predictor of intention to use as per SEM. The difference between the results obtained from the statistical model (using SEM) and machine-learning model (using neural network model) can be attributed to the nature of neural network model (nonlinear and non-compensatory) and relatively higher predictive power of the later model.

\section{Discussion}

Government services depend greatly on the technology platforms such as mobile and other online platforms to reach citizens and residents and achieve greater participation and awareness, higher level of trust, and deeper engagement. With regard to the delivery of upto-date information to residents, the delivery to those living in sparse locations in the Sultanate of Oman has been a long-standing challenge for decision makers in the government sector. The sparse locations pose big challenges for socio-economic development in a developing country. The use of mobile applications may assist in overcoming the challenges in terms of socio-economic development of the entire society and an effective channel to deliver government services. It is evident from our survey results on the basis of data collected from all parts of the Sultanate of Oman that residents are willing to use mobile applications for government services across the country.

This study quantified the influence of six factors on the intention to use mG-App across all parts of the Sultanate of Oman. Five out of the six factors were found to influence citizens' decision to use mG-App. Specifically, performance expectancy, trust, effort expectancy, information quality and facilitation conditions were found to influence the decision to adopt $\mathrm{mG}-\mathrm{App}$ in the Sultanate of Oman. The statistical results summarized in the previous section show that the proposed research model in this study has been able to achieve acceptable level with respect to predictive power of the dependent variable i.e. behavioral intention towards mG-App. In addition, all indices of measurement and structural models were within the prescribed limits. It is also important to note that the examination of the structural models was conducted with and without additional constructs (trust and information quality). As expected, $\mathrm{R}^{2}$ of the UTAUT was $53 \%$ and increased to $64 \%$ on

inclusion of aforementioned additional constructs. Therefore, inclusion of additional constructs has increased predictive power of the proposed research model. 
The results indicate that trust in mG-App is the most important predictor, determining the individuals' behavioral intention towards the new technology. In other words, individuals are intended to perform confidential transactions in mG-Apps by providing personal and credit card information. The quality of updated information and ease in operations builds trust in the mG-Apps. The level of trust in $\mathrm{mG}$-Apps can further be increased by including encryption techniques to facilitate higher order of privacy policies. It can be summarized that the increased level of privacy policies and updated information motivate users to adopt mG-App. This result is consistent with previous studies, which presented that lack of trust considers as an important challenge to accept and use a new system or technology (Alalwan et al. 2017; Alalwan et al. 2016b; Colesca, 2015; Montazemi \& Saremi, 2013; Sun et al., 2014). Further, the results reveal that the performance expectancy is the second most influencing factor determining intention to use mG-App. It is interesting to note that performance expectancy is the most important predictor on behavioral intention in the neural network results. The possible reason of this outcome is the higher predictive power of the neural network models. The functional utilities (performance expectancy) are on the primary focus of attention of the Omani residents for decision to adopt mG-App. Government agencies may enhance their online services through demonstrating and promoting them to the public by showing key useful features. Furthermore, usefulness of government agencies can be increased by introducing new and different technological channels. Ghalandari (2012) confirmed that performance expectancy employs significant effect on individual's behavioral intention towards new technology. Other studies also found performance expectancy as one of the most significant predictors towards the individual's behavioral intention (Alalwan et al. 2017; Alalwan et al. 2016a; Attuquayefio \& Addo, 2014; Martins et al., 2014).

Furthermore, effort expectancy is another important predictor that influences users' intention to use mG-App. This finding shows that Omani residents including expatriates prefer to use an easy to use technology, which requires less efforts and time compared to other old-fashioned methods to perform their financial services and information pertaining to government services using mobile applications. Most of the studies based on the UTAUT have confirmed that there is a statistical and significant relationship between effort expectancy and behavioral intention (Alalwan et al. 2016b; Alalwan et al. 2017; 
Attuquayefio \& Addo, 2014; Ghalandari, 2012). Unlike other studies (Ahmad \& Khalid, 2017; Alalwan et al., 2015; Chong, 2013a; Lallmahomed et al. 2017; Liu et al. 2014), results of this study show that the relationship between social influence and behavioral intention was insignificant, which means that residents in the Sultanate of Oman seem to be least interested in recommending usage of mG-Apps to their relatives and friends. Riffai et al. (2012) also conducted a study in the Sultanate of Oman and found that social influence was not a significant predictor of behavioral intention in the context of mobile banking. In addition, this finding is consistent with some of previous results reported in different information systems domains (Alalwan et al. 2017; Sun et al., 2014).

Next, the results support the fact that facilitating conditions have a positive influence on behavioral intentions to use $\mathrm{mG}-\mathrm{App}$. This finding indicates that the residents pay substantial attention to the available resources, required skill sets and facilities such as better Internet access, secured mobile applications and smartphones to access and use mGApp for using government services through mobile applications. This finding was consistent with a number of other empirical studies in information system domains (Ahmad \& Khalid, 2017; Alalwan et al., 2015; Alalwan et al., 2017; Chong, 2013a; Ghalandari, 2012; Hew et al., 2015; Yang \& Forney, 2013). Finally, the results also found a significant and positive relationship between information quality and behavioral intention to use $\mathrm{mG}$ App. This clearly suggests that the relevant information, timely updates and similar characteristics influence the acceptance and use of mG-App. The findings confirmed that the acceptance of mobile applications by residents can be improved by increasing the information quality of the mobile applications. These findings are consistent with the findings of numerous studies, which confirm the importance of information quality for the user's behavioral intention to use an innovative technology (Akter, D’Ambra \& Ray, 2013; Al-Busaidi \& Al-Shihi, 2012; Alateyah, Crowder \& Wills, 2013; Sharma et al., 2017).

\subsection{Implications for theory}

This study provides a number of useful insights to academics and researchers. Firstly, it has extended the existing literature by adding two additional constructs namely trust and information quality into UTAUT model to explain the behavioral intention towards $\mathrm{mG}$ Apps in the context of a GCC country. From the theoretical point of view, this study will 
add more knowledge in mobile government adoption, e-government studies and specifically in mobile applications studies. Secondly, application of an innovative twostage SEM-NN (i.e. structural equation modelling-neural network) modelling that provides the holistic understanding from analytical point of view. The application of neural network modelling is an attempt to address one of the limitations in several studies based on technology adoption by developing a non-compensatory model to predict behavioral intention of Omani residents towards mG-App. In addition, neural network modelling is non-compensatory in nature that overcomes the weaknesses of compensatory nature of linear structural equation modelling. In this context, it is nothing but assessing the validity of the research model using SEM for understanding the effect of independent constructs on dependent construct. The neural network modelling was employed to validate SEM results and to rank significant independent constructs. Thirdly, the findings of this study complement mobile technology adoption studies in government services. In addition, technological innovation can be extended in adoption research by the outcomes of this study. Finally, this study provides important research findings by examining acceptance of mobile applications for government services in the context of a GCC country like Oman.

\subsection{Implications for practice}

From the practical point of view, the findings of this study reveal the important role of the following constructs: performance expectancy, effort expectancy, trust, facilitating conditions, information quality and behavioral intention. Therefore, the government agencies must keep these constructs in the focus while developing mobile applications for citizen centric services. In addition, the government agencies would correlate these findings while they are planning to develop and implement projects of the similar nature in multiple domains. The result of the study will help Omani government agencies to develop suitable strategies and policies to attract more residents to use $\mathrm{mG}$-Apps. Decision makers can improve the quality of mG-Apps by providing trustworthy and efficient services as performance expectancy and trust are the factors influencing decision to adopt the aforementioned services. We have also validated the impact of performance expectancy and effort expectancy on behavioral intention. In other words, residents give significant importance to the useful mobile applications for government services, which requires minimal efforts in its operations. Therefore, it is recommended that mobile applications 
developers for government services should pay higher attention on reducing the complexities associated with usage and exploration of mobile applications.

Furthermore, development process of mobile applications can be further strengthened by involving some experienced users to receive feedback at the design stage of the applications. For example, Omanuna is a national portal to deliver multiple services such as housing, tourism, traffic \& transport and others by government to residents. One of the key objectives of Omanuna is to develop effective government-community-resident's infrastructure to serve residents by two-way communication between government and residents. Government officials may create a feedback icon for mG-Apps on Omanuna portal to incorporate users' opinion. In addition, the Omani government may develop public-private partnership (PPP) for intelligent and effective use of mG-Apps (see Dwivedi et al. 2017 for detailed discussion)

We also observed the significant relationship between facilitating conditions and behavioral intentions. This finding implies that residents place substantial importance on facilities provided by government to utilize government services on mobile devices. The government should develop short training programs about appropriate usage of facilities through public and private institutions to users on regular intervals across the country. Such services provided by aforementioned institutions would not only help the new and potential users about government services on mobile devices but also make them familiar with newly launched and upcoming services. Moreover, the government can also plan some awareness programs using print and social media.

Moreover, the significant relationship between trust and behavioral intentions towards mG-Apps implies that residents place quite higher importance on security and privacy measures while using government services on mobile devices and needed other resources. The developers and system analysts should pay more attention on developing robust and secure applications, which can be achieved by adding an extra layer of security to minimize the risks associated with the usage of mG-Apps. The robustness and security can be achieved by adopting "Mobile Applications Secure Development Guidelines" published by the Sultanate of Oman. Moreover, the significant impact of information quality on behavioral intention indicates that the residents expect from government to provide precise, accurate, meaningful, relevant, complete and timely information related to 
government services. The expectation becomes even higher in terms of timeliness and accuracy when the information is related to the transactions made through mobile channels. The mobile application developers are recommended to adopt One Web Approach to develop mobile applications so that the same information could be displayed on the screen irrespective of the type of the mobile device. These mobile apps should also have automatic notification facility to receive the latest updates. The public and private agencies should ensure the meaningfulness and timeliness of the information to be delivered to the users.

\section{Conclusion, limitations and future research directions}

This study explored the key factors influencing the residents' behavioral intention to use mG-App in Oman. To conclude, the research provided comprehensive understanding about the critical factors. The findings show that the factors such as performance expectancy, effort expectancy, facilitating conditions, trust, and information quality have positively influenced behavioral intention. These factors strongly influence the decision to use $\mathrm{mG}$ App. Further, the findings also indicate that social influence did not influence behavioral intention, which signifies that the residents in Oman cannot be influenced by the opinions of referent others as far as the use of $\mathrm{mG}-\mathrm{App}$ is concerned. Therefore, residents of Oman are supposed to use mG-Apps because of its usefulness and ease in operations. In addition, it is also observed that user friendly technology increases behavioral intention of users over a period of time. The result of this study will help government agencies to develop suitable strategies to motivate more users to use mobile applications for government services.

Despite the significant contributions, there are some limitations of this study. Firstly, the perception of residents in this study is restricted to Oman and hence it is recommended to take appropriate caution while implementing the proposed research model in the context of other GCC countries. Secondly, the data gathered for this study is cross-sectional in nature and therefore it is recommended to conduct a longitudinal study to assess user's intention over a period of time. Thirdly, majority of the respondents were from the age group 20-40 years and hence it recommended testing the proposed research model with more balance data in terms of age-group. Finally, the effect of demographic variables was not tested as moderators in this study. The future studies may expand this research by 
testing the effect of gender, age, education etc. on the intention as well as the actual usage of mobile applications for government services.

\section{Reference}

Al-Azizi, L., Al-Badi, A.H., \& Al-Zrafi, T. (2018)," Exploring the Factors Influencing Employees' Willingness to Use Mobile Applications in Oman: Using UTAUT Model ", Journal of eGovernment Studies and Best Practices, Vol. 2018 (2018), Article ID 553293, DOI: $10.5171 / 2018$.

Abaza, M. \& Saif, F., (2015), The Adoption of Mobile Government Services in Developing Countries, International Journal of Computer Science Issues, 12 (1), 137-145.

Abdelghaffar, H. \& Magdy, Y., (2012), The adoption of mobile government services in developing countries: The case of Egypt, International Journal of Information, 2 (4), 333-341.

Ahmad, S. Z. \& Khalid, K., (2017), The adoption of M-government services from the user's perspectives: Empirical evidence from the United Arab Emirates, International Journal of Information Management, 37 (5), 367-379.

Akter, S., D’Ambra, J. \& Ray, P., (2013), Development and validation of an instrument to measure user perceived service quality of mHealth, Information \& Management, 50 (4), 181-195.

Al-Busaidi, H. A. S. (2012), A model of intention to use mobile government services, a $\mathrm{PhD}$ thesis at School of Management and Information Systems, Faculty of Business and Law, Victoria University.

Al-Busaidi, K. A. \& Al-Shihi, H., (2012), Key factors to instructors' satisfaction of learning management systems in blended learning, Journal of Computing in Higher Education, 24 (1), 18-39.

Al-Masaeed, S. \& Love, S. (2015), Building a User Centric Success Factors Model for Mobile Government, In Research Methods: Concepts, Methodologies, Tools, and Applications IGI Global, 1579-1599.

Al-Qeisi, K., Dennis, C., Alamanos, E. \& Jayawardhena, C., (2014), Website design quality and usage behavior: Unified Theory of Acceptance and Use of Technology, Journal of Business Research, 67 (11), 2282-2290.

Alalwan, A. A., Dwivedi, Y. K. \& Rana, N. P., (2017), Factors influencing adoption of mobile banking by Jordanian bank customers: Extending UTAUT2 with trust, International Journal of Information Management, 37 (3), 99-110.

Alalwan, A. A., Dwivedi, Y. K., Rana, N. P., Lal, B. \& Williams, M. D., (2015), Consumer adoption of Internet banking in Jordan: Examining the role of hedonic motivation, habit, self-efficacy and trust, Journal of Financial Services Marketing, 20 (2), 145-157.

Alalwan, A. A., Dwivedi, Y. K., Rana, N. P. \& Simintiras, A. C., (2016a), Jordanian consumers' adoption of telebanking: Influence of perceived usefulness, trust and self-efficacy, International Journal of Bank Marketing, 34 (5), 690-709.

Alalwan, A. A., Dwivedi, Y. K., Rana, N. P. \& Williams, M. D., (2016b), Consumer adoption of mobile banking in Jordan: examining the role of usefulness, ease of use, perceived risk and self-efficacy, Journal of Enterprise Information Management, 29 (1), 118-139.

Alarcón, D. \& Sánchez, J. A., (2015), Assessing convergent and discriminant validity in the ADHD$R I V$ rating scale: User-written commands for Average Variance Extracted (AVE), Composite Reliability (CR), and Heterotrait-Monotrait ratio of correlations (HTMT). Spanish STATA Meeting, Accessed on 13-07-2017, Available at: [http://www.stata.com/meeting/spain15/abstracts/ materials/spain15_alarcon.pdf]

Alateyah, S., Crowder, R. M. \& Wills, G. B., (2013), Factors Affecting the Citizen's Intention to Adopt E-government in Saudi Arabia, International Journal of Social, Human Science and Engineering, 7 (9), 80-85. 
Asongu, S. A. \& Nwachukwu, J. C., (2016), The Mobile Phone in the Diffusion of Knowledge for Institutional Quality in Sub-Saharan Africa, World Development, 86, 133-147.

Attuquayefio, S. \& Addo, H., (2014), Review of studies with UTAUT as conceptual framework, European Scientific Journal, 10 (8), 249-258.

Azzalini, A., Browne, R. P., Genton, M. G. \& McNicholas, P. D., (2014), Comparing two formulations of skew distributions with special reference to model-based clustering, arXiv preprint arXiv:1402.5431.

Bennet, M. A., Sankaranarayanan, S. \& Babu, G. S., (2015), Performance and analysis of effective iris recognition system using independent component analysis, Journal of Chemical and Pharmaceutical Sciences, 8 (3), 571-576.

Biel, B., Grill, T. \& Gruhn, V., (2010), Exploring the benefits of the combination of a software architecture analysis and a usability evaluation of a mobile application, Journal of Systems and Software, 83 (11), 2031-2044.

Bonett, D. G. \& Wright, T. A., (2015), Cronbach's alpha reliability: Interval estimation, hypothesis testing, and sample size planning, Journal of Organizational Behavior, 36 (1), 3-15.

Byrne, B. M. (2016), Structural equation modeling with AMOS: Basic concepts, applications, and programming, Routledge.

Chai, S., Herath, T., Park, I. \& Rao, H. R., (2006), Repeated use of e-gov web sites: A satisfaction and confidentiality perspective, International Journal of Electronic Government Research (IJEGR), 2 (3), 1-22.

Chiang, W.-Y. K., Zhang, D. \& Zhou, L., (2006), Predicting and explaining patronage behavior toward web and traditional stores using neural networks: A comparative analysis with logistic regression, Decision Support Systems, 41 (2), 514-531.

Chong, A. Y.-L., (2013a), Mobile commerce usage activities: The roles of demographic and motivation variables, Technological Forecasting and Social Change, 80 (7), 1350-1359.

Chong, A. Y.-L., (2013b), A two-staged SEM-neural network approach for understanding and predicting the determinants of m-commerce adoption, Expert Systems with Applications, 40 (4), 1240-1247.

Chong, A. Y.-L., Liu, M. J., Luo, J. \& Keng-Boon, O., (2015), Predicting RFID adoption in healthcare supply chain from the perspectives of users, International Journal of Production Economics, 159, 66-75.

Colesca, S. E., (2015), Understanding Trust in e-Government, Engineering Economics, 63 (4), 7 15.

Davis, F. D., (1989), Perceived usefulness, perceived ease of use, and user acceptance of information technology, MIS Quarterly, 13 (3), 319-340.

DeLone, W. H. \& McLean, E. R., (1992), Information systems success: The quest for the dependent variable, Information systems research, 3 (1), 60-95.

Delone, W. H. \& McLean, E. R., (2003), The DeLone and McLean model of information systems success: a ten-year update, Journal of management information systems, 19 (4), 9-30.

Dwivedi, Y. K., Rana, N. P., Janssen, M., Lal, B., Williams, M. D. \& Clement, M., (2017), An empirical validation of a unified model of electronic government adoption (UMEGA), Government Information Quarterly, 34 (2), 211-230.

Gao, S., Krogstie, J. \& Siau, K., (2014), Adoption of mobile information services: An empirical study, Mobile Information Systems, 10 (2), 147-171.

Ghalandari, K., (2012), The effect of performance expectancy, effort expectancy, social influence and facilitating conditions on acceptance of e-banking services in Iran: The moderating role of age and gender, Middle-East Journal of Scientific Research, 12 (6), 801-807.

Gilbert, D., Balestrini, P. \& Littleboy, D., (2004), Barriers and benefits in the adoption of egovernment, International Journal of Public Sector Management, 17 (4), 286-301. 
Gupta, B., Dasgupta, S. \& Gupta, A., (2008), Adoption of ICT in a government organization in a developing country: An empirical study, The Journal of Strategic Information Systems, 17 (2), 140-154.

Hanafizadeh, P., Behboudi, M., Koshksaray, A. A. \& Tabar, M. J. S., (2014), Mobile-banking adoption by Iranian bank clients, Telematics and Informatics, 31 (1), 62-78.

Haykin, S., (2001), Neural networks: principles and practice, Bookman.

Hew, J.-J., Lee, V.-H., Ooi, K.-B. \& Wei, J., (2015), What catalyses mobile apps usage intention: an empirical analysis, Industrial Management \& Data Systems, 115 (7), 1269-1291.

Hung, S.-Y., Chang, C.-M. \& Kuo, S.-R., (2013), User acceptance of mobile e-government services: An empirical study, Government Information Quarterly, 30 (1), 33-44.

Koh, C. E., Prybutok, V. R., Ryan, S. D. \& Wu, Y., (2010), A model for mandatory use of software technologies: An integrative approach by applying multiple levels of abstraction of informing science, Informing Science, 13, 177-203.

Lallmahomed, M. Z., Lallmahomed, N., \& Lallmahomed, G. M. (2017). Factors influencing the adoption of e-Government Services in Mauritius. Telematics and Informatics, 34(4), 5772 .

Leong, L.-Y., Hew, T.-S., Tan, G. W.-H. \& Ooi, K.-B., (2013), Predicting the determinants of the NFC-enabled mobile credit card acceptance: A neural networks approach, Expert Systems with Applications, 40 (14), 5604-5620.

Lewis, C. C., Fretwell, C. E., Ryan, J. \& Parham, J. B., (2013), Faculty use of established and emerging technologies in higher education: A unified theory of acceptance and use of technology perspective, International Journal of Higher Education, 2 (2), 22-34.

Li, M.-H. \& Feeney, M. K., (2014), Adoption of Electronic Technologies in Local US Governments Distinguishing Between E-Services and Communication Technologies, The American Review of Public Administration, 44 (1), 75-91.

Liang, Y., Qi, G., Wei, K., \& Chen, J. (2017). Exploring the determinant and influence mechanism of e-Government cloud adoption in government agencies in China. Government Information Quarterly, 34(3), 481-495

Liu, Y., Li, H., Kostakos, V., Goncalves, J., Hosio, S., \& Hu, F. (2014). An empirical investigation of mobile government adoption in rural China: A case study in Zhejiang province. Government Information Quarterly, 31(3), 432-442.

Liébana-Cabanillas, F., Marinković, V. \& Kalinić, Z., (2017), A SEM-neural network approach for predicting antecedents of $\mathrm{m}$-commerce acceptance, International Journal of Information Management, 37 (2), 14-24.

Luo, X., Li, H., Zhang, J. \& Shim, J. P., (2010), Examining multi-dimensional trust and multifaceted risk in initial acceptance of emerging technologies: An empirical study of mobile banking services, Decision support systems, 49 (2), 222-234.

Martins, C., Oliveira, T. \& Popovič, A., (2014), Understanding the Internet banking adoption: A unified theory of acceptance and use of technology and perceived risk application, International Journal of Information Management, 34 (1), 1-13.

MOE, (2013), Ministry of Education, Accessed on 27-8-2016, Available at: [www.moe.gov.om].

Montazemi, A. R. \& Saremi, H. Q., (2013), Factors affecting Internet banking pre-usage expectation formation, In the proceeding of 46th Hawaii International Conference on System Sciences, 4666-4675.

MOP (2000), Ministry Of Manpower, Accessed on 13-7-2017, Available at: [http://www.manpower. gov.om/]

Murugesan, S., (2013), Mobile Apps in Africa, IT Professional, 15 (5), 8-11.

Napitupulu, D. \& Sensuse, D. I., (2014), The critical success factors study for e-government implementation, International Journal of Computer Applications, 89 (16), 23-32.

Naqvi, S. J. \& Al-Shihi, H., (2014), Factors Affecting M-Commerce adoption in Oman using Technology Acceptance Modeling Approach, TEM Journal, 3 (4), 315-322. 
Nixon, M. P., (2016), Human (E) Government Revisited. International Journal of eBusiness and eGovernment Studies, 8(1), 1-18.

Oman T.R.A., (2016), Achievements in the past decade, Accessed on 29-5-2016, Available at: [https://www. tra.gov.om/market/info/the-current-scene]

Payne, J., (2013), Secure Mobile Application Development, IT Professional, 15 (3), 6-9.

Poulton, M. M. (2001). Multi-layer perceptrons and back-propagation learning. In Handbook of Geophysical Exploration: Seismic Exploration, Handbook of Geophysical Exploration: Seismic Exploration, 30, 27-53).

Raitoharju, R. (2014), Information technology acceptance in the Finnish social and healthcare sector: exploring the effects of cultural factors, Publications of the Tuku School of Econonomics

Rana, N. P. \& Dwivedi, Y. K., (2015), Citizen's adoption of an e-government system: Validating extended social cognitive theory (SCT), Government Information Quarterly, 32 (2), 172181.

Rana, N. P., Dwivedi, Y. K., Williams, M. D. \& Weerakkody, V., (2015), Investigating success of an e-government initiative: Validation of an integrated IS success model, Information Systems Frontiers, 17 (1), 127-142.

Rana, N. P., Dwivedi, Y.K., Lal, B., Williams, M.D., and Clement, M. (2017). Citizens' Adoption of an Electronic Government System: Toward a Unified View. Information Systems Frontiers, 19(3), 549-568.

Rana, N. P., Dwivedi, Y. K., Williams, M. D. \& Weerakkody, V., (2016), Adoption of online public grievance redressal system in India: Toward developing a unified view, Computers in Human Behavior, 59, 265-282.

Rouibah, K., (2015), Electronic payment systems use and satisfaction in an arabic country: Evidence from Kuwait, Issues in Information Systems, 16 (2), 149-160.

Royal Oman Police, (2000), Royal Oman Police, Accessed on Available at: [https://www.rop.gov.om]

Shareef, M. A., Archer, N., \& Dwivedi, Y. K. (2012). Examining adoption behavior of mobile government. Journal of Computer Information Systems, 53(2), 39-49.

Sareen, M. \& Chanana, L., (2013), Exploring factors affecting use of mobile government services in India, Problems and Perspectives in Management, 11 (4), 86-93.

Sexton, R. S., Johnson, R. A. \& Hignite, M. A., (2002), Predicting Internet/e-commerce use, Internet Research, 12 (5), 402-410.

Sharma, S. K., Gaur, A., Saddikuti, V. \& Rastogi, A., (2017), Structural equation model (SEM)neural network $(\mathrm{NN})$ model for predicting quality determinants of e-learning management systems, Behaviour \& Information Technology, 36 (10), 1053-1066.

Sharma, S. K., Joshi, A. \& Sharma, H., (2016), A multi-analytical approach to predict the Facebook usage in higher education, Computers in Human Behavior, 55, 340-353.

Sim, J.-J., Tan, G. W.-H., Wong, J. C., Ooi, K.-B. \& Hew, T.-S., (2014), Understanding and predicting the motivators of mobile music acceptance-a multi-stage MRA-artificial neural network approach, Telematics and Informatics, 31 (4), 569-584.

Sun, Y., Liu, L., Peng, X., Dong, Y. \& Barnes, S. J., (2014), Understanding Chinese users' continuance intention toward online social networks: an integrative theoretical model, Electronic Markets, 24 (1), 57-66.

Tam, C. \& Oliveira, T., (2016), Understanding the impact of m-banking on individual performance: DeLone \& McLean and TTF perspective, Computers in Human Behavior, 61, 233-244.

Tan, G. W.-H., Ooi, K.-B., Leong, L.-Y. \& Lin, B., (2014), Predicting the drivers of behavioral intention to use mobile learning: A hybrid SEM-Neural Networks approach, Computers in Human Behavior, 36, 198-213.

The Public Authority for Consumer Protection, (2000), The Public Authority for Consumer Protection, Accessed on 26-08-2016, Available at: [http://pacp.gov.om] 
United Nations (2014), Government Survey 2014: E-government for the Future We Want, United Nations Department of economic and social affairs.

UN E-Government Survey (2014). E-Government Survey 2014. Retrieved from:<http://unpan3.un.org/egovkb/Portals/egovkb/Documents/un/2014-Survey/

E-Gov_Complete_Survey-2014.pdf $>$.

Veeramootoo, N., Nunkoo, R., \& Dwivedi, Y. K. (2018). What determines success of an egovernment service? Validation of an integrative model of e-filing continuance usage. Government Information Quarterly, 35(2), 161-174.

Venkatesh, V., Morris, M. G., Davis, G. B. \& Davis, F. D., (2003), User acceptance of information technology: Toward a unified view, MIS Quarterly, 425-478.

Venkatesh, V., Thong, J. Y., Chan, F. K., Hu, P. J. H. \& Brown, S. A., (2011), Extending the twostage information systems continuance model: Incorporating UTAUT predictors and the role of context, Information Systems Journal, 21 (6), 527-555.

Venkatesh, V., Thong, J. Y. \& Xu, X., (2012), Consumer acceptance and use of information technology: extending the unified theory of acceptance and use of technology, MIS Quarterly, 157-178.

Viechtbauer, W., Smits, L., Kotz, D., Budé, L., Spigt, M., Serroyen, J. \& Crutzen, R., (2015), A simple formula for the calculation of sample size in pilot studies, Journal of clinical epidemiology, 68 (11), 1375-1379.

Wang, Y.-S. \& Liao, Y.-W., (2008), Assessing eGovernment systems success: A validation of the DeLone and McLean model of information systems success, Government Information Quarterly, 25 (4), 717-733.

Williams, M. D., Rana, N. P., Dwivedi, Y. K. \& Lal, B., (2011), Is UTAUT really used or just cited for the sake of it? a systematic review of citations of UTAUT's originating article, In the proceeding of European Conference on Information Systems (ECIS2011), 231

Yang, K. \& Forney, J. C., (2013), The moderating role of consumer technology anxiety in mobile shopping adoption: differential effects of facilitating conditions and social influences, Journal of Electronic Commerce Research, 14 (4), 334.

Zamami, I. \& Memon, M., (2016), Establishing Model of Mobile Government Services at Saudi Arabia, Sindh University Research Journal-SURJ (Science Series), 48 (4D), 91-96.

Zhou, T., (2012), Understanding users' initial trust in mobile banking: An elaboration likelihood perspective, Computers in Human Behavior, 28 (4), 1518-1525.

Zhou, T., Lu, Y. \& Wang, B., (2010), Integrating TTF and UTAUT to explain mobile banking user adoption, Computers in Human Behavior, 26 (4), 760-767.

Appendix A

\begin{tabular}{|c|c|c|c|}
\hline Construct & Measurement Item & Factor loading & $\begin{array}{l}\text { Cronbach's } \\
\text { alpha }\end{array}$ \\
\hline \multirow{4}{*}{$\begin{array}{l}\text { Performance } \\
\text { Expectancy }\end{array}$} & I use mG-Apps to save my time and efforts. & 0.710 & \multirow{4}{*}{0.86} \\
\hline & I feel mG-Apps are useful & 0.792 & \\
\hline & $\begin{array}{l}\text { Using mG-App enables me to request services more } \\
\text { faster }\end{array}$ & 0.814 & \\
\hline & $\begin{array}{l}\text { Using mG-App increases the productivity in terms of } \\
\text { actions }\end{array}$ & 0.776 & \\
\hline \multirow{4}{*}{$\begin{array}{l}\text { Effort } \\
\text { Expectancy }\end{array}$} & $\begin{array}{l}\text { My interaction with mG-Apps is clear and } \\
\text { understandable }\end{array}$ & 0.762 & \multirow{4}{*}{0.84} \\
\hline & $\begin{array}{l}\text { It would be easy for me to become skillful at using } \\
\text { mG-App. }\end{array}$ & 0.729 & \\
\hline & I find mG-App easy to use & 0.674 & \\
\hline & Learning to operate the mG-App is easy for me & 0.785 & \\
\hline
\end{tabular}




\begin{tabular}{|c|c|c|c|}
\hline \multirow{4}{*}{$\begin{array}{l}\text { Social } \\
\text { Influence }\end{array}$} & $\begin{array}{l}\text { People who influence my behavior think that I should } \\
\text { use mG-App. }\end{array}$ & 0.827 & \multirow{4}{*}{0.70} \\
\hline & $\begin{array}{l}\text { People who are important to me think that I should } \\
\text { use mG-App }\end{array}$ & 0.921 & \\
\hline & $\begin{array}{l}\text { The government agencies management has been } \\
\text { helpful in the use of mG-App }\end{array}$ & 0.716 & \\
\hline & $\begin{array}{l}\text { In general, the government agencies have supported } \\
\text { the use of mG-App }\end{array}$ & 0.752 & \\
\hline \multirow{3}{*}{$\begin{array}{l}\text { Facilitating } \\
\text { Conditions }\end{array}$} & I have necessary resources to use mG-App. & 0.818 & \multirow{3}{*}{0.62} \\
\hline & I have necessary knowledge to use mG-App. & 0.696 & \\
\hline & $\begin{array}{l}\text { A specific person (or group) is available for } \\
\text { assistance with mG-App difficulties }\end{array}$ & 0.712 & \\
\hline \multirow{4}{*}{ Trust } & Transactions using mG-Apps are safe & 0.853 & \multirow{4}{*}{0.92} \\
\hline & Users privacy is well protected in mG-App. & 0.689 & \\
\hline & Mobile transactions are reliable in mG-App. & 0.887 & \\
\hline & Security measures in mG-App are enough & 0.776 & \\
\hline \multirow{2}{*}{$\begin{array}{l}\text { Information } \\
\text { Quality }\end{array}$} & The information provided by mG-App is up-to-date. & 0.768 & \multirow{2}{*}{0.81} \\
\hline & The information provided by mG-App is complete & 0.861 & \\
\hline \multirow{3}{*}{$\begin{array}{l}\text { Behavioral } \\
\text { Intention }\end{array}$} & $\begin{array}{l}\text { I intend to continue using mG-App in the next } \\
\text { months }\end{array}$ & 0.926 & \multirow{3}{*}{0.88} \\
\hline & I plan to use the mG-App in the next months & 0.759 & \\
\hline & $\begin{array}{l}\text { My intentions are to use the mG-App in the next } \\
\text { months }\end{array}$ & 0.868 & \\
\hline
\end{tabular}

